Abstracta Iranica

Revue bibliographique pour le domaine irano-aryen

Volume 40-41 | 2019

Comptes rendus des publications de 2017-2018

\title{
Antonio Invernizzi. “L'Iran arsacide tra Achemenidi e Sasanidi"
}

\section{Leonardo Gregoratti}

\section{(2) OpenEdition}

1 Journals

\section{Electronic version}

URL: http://journals.openedition.org/abstractairanica/49716

DOI: 10.4000/abstractairanica.49716

ISBN: 1961-960X

ISSN: 1961-960X

Publisher:

CNRS (UMR 7528 Mondes iraniens et indiens), Éditions de l'IFRI

Electronic reference

Leonardo Gregoratti, "Antonio Invernizzi. "L'Iran arsacide tra Achemenidi e Sasanidi"', Abstracta Iranica [Online], Volume 40-41 | 2019, document 38, Online since 30 October 2019, connection on 20 April 2021. URL: http://journals.openedition.org/abstractairanica/49716 ; DOI: https://doi.org/10.4000/ abstractairanica. 49716

This text was automatically generated on 20 April 2021.

Tous droits réservés 


\title{
Antonio Invernizzi. "L'Iran arsacide tra Achemenidi e Sasanidi"
}

\author{
Leonardo Gregoratti
}

\section{REFERENCES}

Antonio Invernizzi. "L'Iran arsacide tra Achemenidi e Sasanidi" in Pierfrancesco Callieri, Adriano V. Rossi (eds.). Civiltà dell'Iran, Passato Presente Futuro, Atti del Convegno Internazionale Roma, 22-23 febbraio 2013. Roma: Scienze e Lettere, 2018, p. 99-114

1 The famous Italian art historian in this paper offers a series of reflections concerning the different cultural and artistic elements, which interacted with each other through the history and evolution of the Arsacid Empire in the different expressions of Parthian art. Elements of Hellenistic art already present in Achaemenid time became part of a common and widespread artistic language in Western Asia after Alexander, and continued playing a relevant part in the artistic expression of the early Arsacid period. The naturalistic characteristics of Parthian sculptural art at Nisa inspired by Hellenistic art and artists coexisted with a static organization of the space and the disposition of the figures present in the paintings. The latter element, an evident heritage of ancient Persian art, will be further developed in the Arsacid Royal reliefs and will characterize the sculptural art of the following Sasanid period. In many cases like in the architectural decoration, the Hellenic inspiration remains the main component while the buildings' planimetry and structures do not differ from those of the Achaemenid palaces. The author points out the fact that pre-Greek Iranian elements coexisted and interacted with Hellenistic ones in Parthian period in different ways and through different artistic expressions, developing the basic schemes later adopted by Sassanid art. 


\section{AUTHORS}

\section{LEONARDO GREGORATTI}

Durham University 